\title{
GEORGE ELMER FORSYTHE
}

\author{
January 8, 1917-April 9, 1972
}

With the sudden death of George Forsythe, modern numerical analysis has lost one of its earliest pioneers, an influential leader who helped bring numerical analysis and computer science to their present positions. We in computing have been fortunate to have benefited from George's abilities, and we all feel a deep sense of personal and professional loss.

Although George's interest in calculation can be traced back at least to his seventh grade attempt to see how the digits repeated in the decimal expansion of 10000/7699, his early research was actually in summability theory, leading to his Ph.D. in 1941 under J. D. Tamarkin at Brown University. A brief period at Stanford thereafter was interrupted by his Air Force service, during which he became interested in meteorology, co-authoring an influential book in that field. George then spent a year at Boeing, where his interest in scientific computing was reawakened, and in 1948 he began his fruitful association with the Institute for Numerical Analysis of the National Bureau of Standards on the UCLA campus, remaining at UCLA for three years after leaving the Institute in 1954. In 1957 he rejoined the Mathematics Department at Stanford as Professor, became director of the Computation Center, and eventually Chairman of the Computer Science Department when it was founded in 1965.

George greatly influenced the development of modern numerical analysis, especially in numerical linear algebra where his 1953 classification of methods for solving linear systems gave structure to a field of great importance. His books on partial differential equations and on linear systems continue to be standard sources and texts; among his nearly 80 scholarly papers are treatments of orthogonal polynomials, relaxation methods, education, and the areas mentioned above.

Perhaps George's greatest contribution was to the growth of computer science education. He was largely responsible for the establishment in 1961 of Stanford's Division of Computer Sciences which served as a model for many departments in this field. He was one of the few with vision to perceive computing as a genuine academic discipline with a brilliant future, and he argued with great success for its recognition as such, especially during his 1964-66 term as President of the Association for Computing Machinery. In addition to his service as ACM president, George devoted much time and energy to a variety of professional organizations, having held high positions as well in the Society for Industrial and Applied Mathematics and the American Mathematical Society.

All of the work mentioned above serves partly as a monument to George Forsythe. He will continue to influence future students in computing, partly by his impact on

The author had the opportunity to examine memorial notices prepared by $\mathbf{J}$. Herriot and by $\mathrm{D}$. Knuth for the August, 1972 issue of the Communications of the ACM and by A. Householder for the March, 1973 issue of the SIAM Journal on Numerical Analysis; the latter two articles contain bibliographies of Forsythe's work. 
the development of the field, partly by his own writings and the prestigious series of more than 75 books edited by him, and partly by the many students who have learned from him, including the $16 \mathrm{Ph} . \mathrm{D}$. students he supervised, many of whom have become influential in their own right. By those of us who knew him as a kind man interested in others, by those of us who knew him as a gifted leader, George Forsythe will be missed.

JAMES W. DANIEL

\section{Publications Cited Principally}

Dynamic Meteorology (with Jörgen Holmboe and William Gustin), John Wiley \& Sons, New York, 1945,378 pp.

Finite-Difference Methods for Partial Differential Equations (with Wolfgang Wasow), John Wiley \& Sons, New York, 1960, 444 pp. MR 23 \# B3156.

Computer Solution of Linear Algebraic Equations (with Cleve Moler), Prentice-Hall, Englewood Cliffs, N.J., 1967, 153 pp. IR 36 \#2306.

Tentative Classification of Methods and Bibliography on Solving Linear Equations. Simultaneous Linear Equations and the Determination of Eigenvalues, Nat. Bur. Standards Appl. Math. Series, no. 29, U.S. Government Printing Office, Washington, D.C., 1953, pp. $1-28$. 